\title{
Non-coding RNA ANRIL and the number of plexiform neurofibromas in patients with NF1 microdeletions
}

Tanja Mußotter ${ }^{1}$, Lan Kluwe ${ }^{2,3}$, Josef Högel ${ }^{1}$, Rosa Nguyen ${ }^{3}$, David N Cooper ${ }^{4}$, Victor-Felix Mautner ${ }^{3}$ and Hildegard Kehrer-Sawatzki ${ }^{1 *}$

\begin{abstract}
Background: Neurofibromatosis type-1 (NF1) is caused by mutations of the NF1 gene at 17q11.2. In 95\% of non-founder NF1 patients, NF1 mutations are identifiable by means of a comprehensive mutation analysis. 5-10\% of these patients harbour microdeletions encompassing the NF1 gene and its flanking regions. NF1 is characterised by tumours of the peripheral nerve sheaths, the pathognomonic neurofibromas. Considerable inter- and intra-familial variation in expressivity of the disease has been observed which is influenced by genetic modifiers unrelated to the constitutional NF1 mutation. The number of plexiform neurofibromas (PNF) in NF1 patients is a highly heritable genetic trait. Recently, SNP rs2151280 located within the non-coding RNA gene ANRIL at 9p21.3, was identified as being strongly associated with PNF number in a family-based association study. The T-allele of rs2151280, which correlates with reduced ANRIL expression, appears to be associated with higher PNF number. ANRIL directly binds to the SUZ12 protein, an essential component of polycomb repressive complex 2, and is required for SUZ12 occupancy of the CDKN2A/CDKN2B tumour suppressor genes as well as for their epigenetic silencing.

Methods: Here, we explored a potential association of PNF number and PNF volume with SNP rs2151280 in 29 patients with constitutional NF1 microdeletions using the exact Cochran-Armitage test for trends and the exact Mann-Whitney-Wilcoxon test. Both the PNF number and total tumour volume in these 29 NF1 patients were assessed by whole-body MRI. The NF1 microdeletions observed in these 29 patients encompassed the NF1 gene as well as its flanking regions, including the SUZ12 gene.
\end{abstract}

Results: In the 29 microdeletion patients investigated, neither the PNF number nor PNF volume was found to be associated with the T-allele of rs 2151280.

Conclusion: Our findings imply that, at least in patients with NF1 microdeletions, PNF susceptibility is not associated with rs2151280. Although somatic inactivation of the NF1 wild-type allele is considered to be the PNF-initiating event in NF1 patients with intragenic mutations and patients with NF1 microdeletions, both patient groups may differ with regard to tumour progression because of the heterozygous constitutional deletion of SUZ12 present only in patients with NF1 microdeletions.

\footnotetext{
* Correspondence: hildegard.kehrer-sawatzki@uni-ulm.de

${ }^{1}$ Institute of Human Genetics, University of Ulm, Albert-Einstein-Allee 11, Ulm, Germany

Full list of author information is available at the end of the article
}

\section{Biomed Central}

(c) 2012 Mußotter et al.; licensee BioMed Central Ltd. This is an Open Access article distributed under the terms of the Creative Commons Attribution License (http://creativecommons.org/licenses/by/2.0), which permits unrestricted use, distribution, and reproduction in any medium, provided the original work is properly cited. 


\section{Background}

Neurofibromatosis type 1 (NF1; MIM\# 613113) is an autosomal dominant inherited disease, with an incidence of 1 in 3000, caused by mutations of the NF1 gene at 17q11.2. In $95 \%$ of non-founder NF1 patients, NF1 gene mutations are identified when a comprehensive NF1 mutation analysis is applied, including an RNA-based core assay supplemented with methods to identify NF1 microdeletions [1]. The proportion of patients with large deletions (termed NF1 microdeletions) that encompass the entire NF1 gene and its flanking regions among all patients with NF1 is $5-10 \%$ [2].

NF1 is a tumour predisposition syndrome characterised by tumours of the peripheral nerve sheaths including the pathognomonic neurofibromas. Cutaneous or dermal neurofibromas (DNF) usually grow during puberty or early adulthood at the end of single peripheral nerves and form small round tumours on the skin which never become malignant. In contrast to DNF, plexiform neurofibromas (PNF) grow along large nerve trunks involving several nerve bundles and mostly represent much larger and more complex tumours than DNF. PNF are usually congenital [3], can grow continuously and may cause organ compression, neurologic impairment and motor dysfunction. At least $10 \%$ of all PNF transform into malignant peripheral nerve sheath tumours (MPNST) which are the major cause of NF1-associated mortality [4].

NF1 is associated with considerable inter- and intrafamilial variability in phenotypic expression. Nevertheless, the familial aggregation of specific symptoms suggests the influence of a strong genetic component unrelated to the constitutional NF1 mutation [5,6]. One of the phenotypic traits with the highest estimated heritability in NF1 is the number of PNF, suggesting that one or more modifier genes might influence PNF susceptibility [6]. Recently, a single nucleotide polymorphism (SNP) rs2151280, located within the non-coding RNA gene ANRIL at 9p21.3, has been identified as being associated with the number of PNF in a family-based association study [7]. ANRIL (antisense non-coding RNA in the INK4 locus) is transcribed in the antisense orientation to the CDKN2A/ARF and $C D K N 2 B$ genes (Figure 1 ) and is known to influence their expression [8-10]. CDKN2A/ARF and CDKN2B are three tumour suppressor genes which play a central role in cell cycle inhibition, senescence and stress-induced apoptosis [11]. Importantly, homozygous deletion or expression silencing of these genes has been observed in a subset of PNF, atypical neurofibromas (considered as premalignant tumours) and MPNSTs indicative of their role during the malignant progression of peripheral nerve sheath tumours $[7,12,13]$. However, not only the malignant progression of PNF but also their formation may be influenced by genes at 9p21.3. This conclusion has been drawn from the observed association between the number of PNF in NF1 families and SNP rs2151280 located within the ANRIL gene. The T-allele of rs2151280 has been found to be associated with a higher number of PNF [7]. These authors investigated a total of 1105 individuals (740 NF1 patients and 365 unaffected relatives from 306 French NF1 families). It is however unclear how the number of PNF was assessed in these 740 NF1 patients. Whilst PNF can be externally visible tumours, they may also present as internal

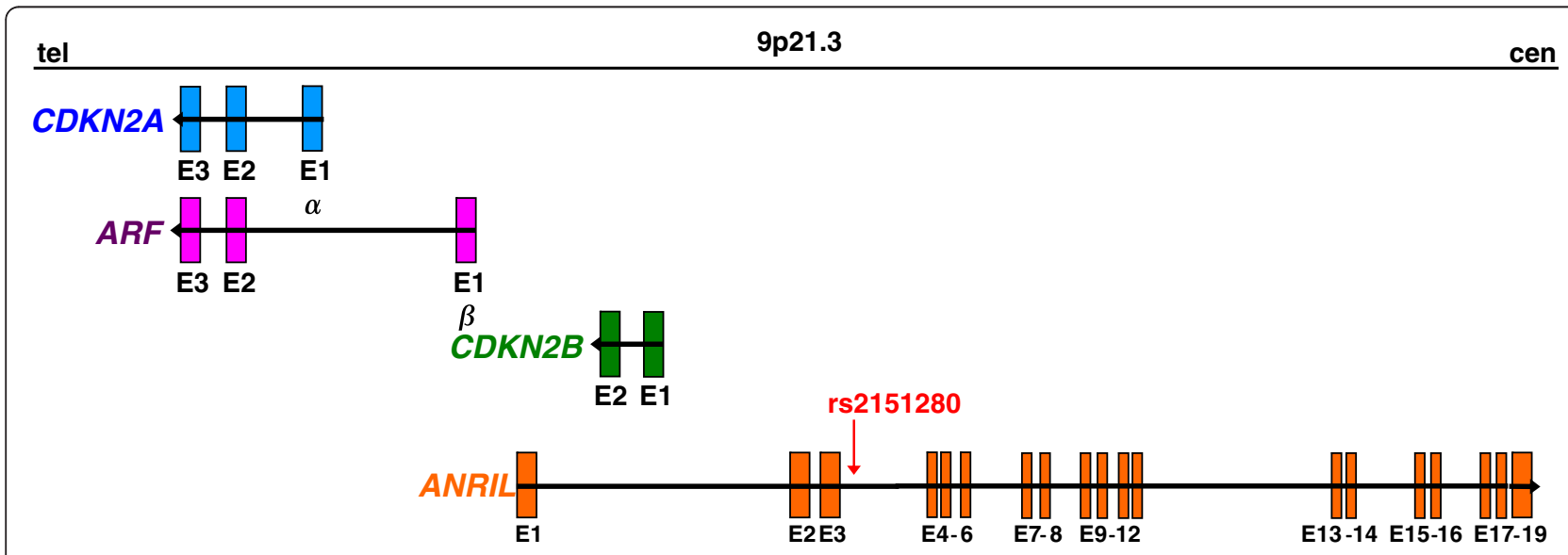

Figure 1 Schematic representation of the genomic organization of the CDKN2A/ARF-CDKN2B gene cluster on chromosome 9p21.3. CDKN2A and ARF share the same exons 2 and 3 but include different first exons (1a and $1 \beta$ ). The alternative splicing of exon $1 a$ or exon $1 \beta$ to exons 2 and 3 gives rise to a difference in the reading frames between CDKN2A and ARF, thereby accounting for the absence of any amino acid homology between the proteins encoded by CDKN2A and ARF. The long non-coding RNA ANRIL (antisense non-coding RNA in the INK4 in locus) gene contains 19 exons and is transcribed in the antisense orientation of the CDKN2A/ARF-CDKN2B gene cluster. Black arrows indicate the transcriptional orientation of the genes at 9p21.3. The red arrow indicates the relative position of the SNP rs 2151280 within ANRIL intron 3. 
asymptomatic tumours which are not detectable by physical examination. Hence, the accurate and reliable detection of all PNF in a given patient with NF1 requires whole-body magnetic resonance imaging (MRI) [14]. In this study, we analysed 29 patients with non-mosaic NF1 microdeletions. The number of PNF as well as the total PNF volume exhibited by these patients has been thoroughly analysed by whole-body MRI and volumetric analysis in a previous study [15]. The 29 patients with NF1 microdeletions analysed here presented with different numbers of PNF (ranging from 0 to 5 PNF per patient). The purpose of our study was to examine if there was an association between ANRIL SNP rs2151280 and the number or volume of PNF observed in patients with NF1 microdeletions.

\section{Methods}

Patients and number or volume of PNF

All 29 NF1 patients (or their parents) investigated gave their written informed consent for the studies to be performed. This study was approved by the university ethics committees of the participating institutions. The patients harboured non-mosaic (i.e. constitutional) NF1 microdeletions (Table 1). The extent of these deletions, as well as the absence of normal cells without the deletion, has already been determined by FISH and sequence analysis

Table 1 Number of plexiform neurofibromas (PNF), tumour volume and genotype of SNP rs2151280 in 29 patients with non-mosaic NF1 microdeletions

\begin{tabular}{|c|c|c|c|c|c|c|c|}
\hline Patient & $\begin{array}{c}\text { Age } \\
\text { (years) }\end{array}$ & Sex & $\begin{array}{c}\text { Total } \\
\text { tumour } \\
\text { volume }(\mathrm{ml})\end{array}$ & $\begin{array}{c}\text { Relative } \\
\text { tumour } \\
\text { volume }\left(\mathrm{ml} / \mathrm{kg}^{\mathrm{a}}\right)\end{array}$ & $\begin{array}{l}\text { Number } \\
\text { of }^{\text {PNF }}{ }^{b}\end{array}$ & $\begin{array}{c}\text { Extent } \\
\text { (type) of NF1 } \\
\text { microdeletion }\end{array}$ & $\begin{array}{c}\text { Genotype of } \\
\text { rs2151280 }\end{array}$ \\
\hline 682 & 53 & female & 0 & 0 & 0 & 1.4-Mb $(1)^{\mathrm{c}}$ & $\mathrm{C} / \mathrm{T}$ \\
\hline 1058 & 4 & female & 0 & 0 & 0 & 1.4-Mb $(1)^{\mathrm{c}}$ & $\mathrm{C} / \mathrm{T}$ \\
\hline 748 & 21 & female & 0 & 0 & 0 & $1.4-\mathrm{Mb}(1)^{\mathrm{c}}$ & $\mathrm{C} / \mathrm{C}$ \\
\hline 876 & 15 & female & 0 & 0 & 0 & 1.4-Mb $(1)^{\mathrm{c}}$ & $\mathrm{T} / \mathrm{T}$ \\
\hline 975 & 11 & male & 0 & 0 & 0 & 1.4-Mb $(1)^{\mathrm{c}}$ & $\mathrm{C} / \mathrm{C}$ \\
\hline 991 & 18 & male & 0 & 0 & 0 & 1.4-Mb $(1)^{\mathrm{c}}$ & $\mathrm{C} / \mathrm{T}$ \\
\hline 807 & 18 & female & 0 & 0 & 0 & 1.4-Mb $(1)^{\mathrm{c}}$ & $C / C$ \\
\hline 284 & 14 & female & 0 & 0 & 0 & $1.4-\mathrm{Mb}(1)^{\mathrm{c}}$ & $\mathrm{C} / \mathrm{T}$ \\
\hline 1053 & 28 & female & 1889 & 30.5 & 1 & 1.4-Mb (1) & $\mathrm{C} / \mathrm{C}$ \\
\hline 272 & 16 & female & 258 & 4.8 & 1 & 3-Mb (atypical) ${ }^{d}$ & $\mathrm{C} / \mathrm{C}$ \\
\hline 321 & 23 & male & 54 & 0.6 & 1 & 1.4-Mb $(1)^{\mathrm{c}}$ & $\mathrm{C} / \mathrm{C}$ \\
\hline 793 & 45 & male & 39 & 0.43 & 1 & 1.4-Mb $(1)^{\mathrm{c}}$ & C/C \\
\hline 82 & 20 & female & 28 & 0.35 & 1 & 2.7-Mb (atypical) & $\mathrm{T} / \mathrm{T}$ \\
\hline 515 & 39 & female & 13 & 0.15 & 1 & 1.4-Mb $(1)^{\mathrm{c}}$ & $\mathrm{C} / \mathrm{T}$ \\
\hline 978 & 9 & female & 10 & 0.33 & 1 & 1.4-Mb $(1)^{\mathrm{c}}$ & $\mathrm{C} / \mathrm{T}$ \\
\hline 917 & 31 & female & 8 & 0.12 & 1 & 1.4-Mb $(1)^{\mathrm{c}}$ & $\mathrm{C} / \mathrm{C}$ \\
\hline 283 & 40 & female & 463 & 6.4 & 2 & 1.4-Mb $(1)^{\mathrm{c}}$ & $\mathrm{C} / \mathrm{T}$ \\
\hline 726 & 28 & female & 215 & 2.05 & 2 & 1.4-Mb $(1)^{\mathrm{c}}$ & $\mathrm{T} / \mathrm{T}$ \\
\hline 941 & 15 & male & 20 & 0.28 & 2 & 1.4-Mb (1) ${ }^{\mathrm{c}}$ & $\mathrm{C} / \mathrm{T}$ \\
\hline 463 & 26 & male & 5677 & 77.8 & 3 & 2-Mb (atypical) ${ }^{f}$ & $\mathrm{C} / \mathrm{T}$ \\
\hline 1056 & 38 & male & 4986 & 59.4 & 3 & 1.4-Mb $(1)^{\mathrm{c}}$ & $\mathrm{C} / \mathrm{T}$ \\
\hline 928 & 28 & female & 468 & 9.0 & 3 & 1.3-Mb (atypical) ${ }^{\mathrm{g}}$ & $\mathrm{C} / \mathrm{T}$ \\
\hline 714 & 26 & female & 321 & 5.35 & 3 & 1.4-Mb $(1)^{\mathrm{c}}$ & $\mathrm{C} / \mathrm{C}$ \\
\hline 579 & 17 & male & 8018 & 114.5 & 4 & 1.4-Mb $(1)^{\mathrm{c}}$ & $\mathrm{C} / \mathrm{T}$ \\
\hline 1057 & 17 & male & 3896 & 62.8 & 4 & 1.2-Mb $(2)^{\mathrm{h}}$ & $\mathrm{C} / \mathrm{T}$ \\
\hline 33 & 24 & male & 724 & 9.3 & 4 & 1.4-Mb $(1)^{\mathrm{c}}$ & $\mathrm{C} / \mathrm{C}$ \\
\hline 857 & 3 & female & 656 & 29.8 & 4 & 1.4-Mb $(1)^{\mathrm{c}}$ & $\mathrm{C} / \mathrm{T}$ \\
\hline 866 & 16 & female & 669 & 10.6 & 5 & 1.4-Mb $(1)^{\mathrm{c}}$ & $\mathrm{C} / \mathrm{T}$ \\
\hline 1059 & 22 & male & 247 & 3.43 & 5 & 1.4-Mb $(1)^{\mathrm{c}}$ & $\mathrm{C} / \mathrm{T}$ \\
\hline
\end{tabular}

a: Tumour volume relative to body weight of the patient on the MRI scan date.

b: The plexiform neurofibromas (PNF) counted were $>3 \mathrm{~cm}$ in diameter.

c: as reported in [16], d: as reported in [17], e: published in [18]; f: published in [19]; g: as published in [20]; h: as published in [21]. 
of the breakpoints using DNA derived from peripheral blood of the patients as described previously [16-21].

The number of plexiform neurofibromas (PNF) and the total tumour volume exhibited by the 29 patients with NF1 microdeletions have been investigated in our previous study by whole-body magnetic resonance imaging (MRI) and subsequent volumetric evaluation of the tumours [15]. In brief, the entire body of each patient was investigated in a series of $10 \mathrm{~mm}$ slices performed by the 1.5 Tesla Siemens Magnetom 63 SP/Symphony/Avanto scanner (Siemens, Munich, Germany). PNF were detected based on their characteristic appearance as signal-intense lesions $>3 \mathrm{~cm}$ in their longest diameter. The tumour volume was calculated using MedX software (v3.42; Sensor Systems, Inc, Sterling, Virginia) as previously described [14]. PNF are often complex tumours that grow along nerves and the extent of each tumour was carefully evaluated by the analysis of multiple subsequent images.

\section{Genotype of SNP rs2151280}

The genotype of the single nucleotide polymorphism (SNP) rs2151280, located within intron 3 of the ANRIL gene, was investigated by PCR amplification of the respective genomic region and subsequent sequence analysis of PCR fragments amplified from blood-derived DNA of the 29 patients with NF1 microdeletions. PCRs were performed with primer 5/ GGGAAGAGATGAAGTAGTCAATAAAA 3/ and primer 5/ CCCTCAGCAGCACTTATTTTC 3\%. DNA was extracted from whole blood using the DNeasy Blood and Tissue Kit (Qiagen, Hilden, Germany).

\section{Statistical analysis}

In order to explore the potential association between the number of PNF in the 29 patients with NF1 microdeletions and the genotype of SNP rs2151280, we used two different statistical tests, the exact Cochran-Armitage test for trends and the exact Mann-Whitney-Wilcoxon test. To assess the extent of any association between the tumour volume and rs2151280, the exact Mann-Whitney-Wilcoxon test was applied. An adjustment for age was performed by means of a generalized linear model with a negative binomial distribution and a log-link function. Correlations between the number of PNF, the tumour volume observed and the age of the patients were tested for by determination of the Spearman rank correlation coefficient. Statistical analyses were performed using Statistical Analysis System (SAS) software.

\section{Results}

In the present study, we investigated the potential association between the T-allele of SNP rs2151280 and both the number and volume of the PNF exhibited by 29 patients with non-mosaic NF1 microdeletions. These patients harboured a total of 52 PNF $>3 \mathrm{~cm}$ as determined previously by whole-body magnetic resonance imaging (MRI) [15]. Tumours smaller than $3 \mathrm{~cm}$ in diameter were not included in the analysis because these tumours cannot be evaluated by volumetric analysis. At least 13 (25\%) of 52 tumours analysed were not visible by external physical examination but were detected exclusively by MRI.

We used the Cochran-Armitage test for trends to investigate a potential association between the number of PNF observed in the 29 patients with NF1 microdeletions and SNP rs2151280 . By means of this test, an association between variable (a) with two categories and variable (b) with $>2$ categories was investigated. In the context of this study, variable (a) represents the genotype of SNP rs2151280 observed in the 29 patients. Variable (a) has been classified into two categories: category \#1 represents the genotypes homozygous for the C-allele whereas category \#2 represents the CT and TT genotypes of SNP rs2151280. Variable (b) represents the number of PNF observed, with six distinct categories being classified, ranging from category \#1 (no PNF), category \#2 (one PNF), category \#3 (two PNF) etc. up to category \#6 (five PNF) (Table 1). Within each category of variable (b), the frequency of categories \#1 and \#2 of variable (a) was investigated. In other words, all 29 patients were classified into categories depending upon the number of PNF observed. Subsequently, the frequency of the CC genotype vs. the CT and TT genotypes was assessed for each category of patient distinguishable by PNF number. A significant association between the PNF number and the frequency of the CC vs. CT/TT genotypes was not observed $(P=0.20$, exact CochranArmitage test for trends).

The number of PNF in the 10 patients with a CC genotype ranged from 0 to 4 tumours with a mean value of 1.2 PNF per patient. By contrast, in the 19 patients with the genotype CT or TT, the number of PNF ranged from 0 to 5 with a mean value of 2.1. However, the observed difference between these groups of patients (those with a CC genotype and those with a CT or TT genotype) did not attain statistical significance $(P=0.21$, exact Mann-Whitney-Wilcoxon test). Although PNF are mostly congenital tumours and hence the age of the patients investigated is not considered to be critical, we included an adjustment for age in our comparisons. Again, the difference in the PNF number observed in both patient groups was not found to be significant $(P=$ 0.16 , with an adjustment for age).

We also investigated a putative association between the tumour volume normalized against body weight and the rs2151280 genotype (CC vs. CT and TT genotypes) in the 29 NF1 microdeletion patients. In the group of patients with the $\mathrm{CC}$ genotype, the mean tumour volume was $5.1 \mathrm{ml} / \mathrm{kg}$ whereas the median tumour volume 
was $0.52 \mathrm{ml} / \mathrm{kg}$ (95\% CI: 0.00 - 9.30). In the 19 patients with CT or TT genotypes, the mean and median tumour volume were $19.8 \mathrm{ml} / \mathrm{kg}$ and $2.05 \mathrm{ml} / \mathrm{kg}$ (95\% CI: 0.15 29.80), respectively. Although both groups of patients differed considering the median tumour volume, the confidence intervals overlap to a large extend. A significant difference in tumour volume was not detected comparing both groups of patients ( $P=0.52$, exact Mann-WhitneyWilcoxon test; $P=0.19$ with adjustment for age). We also did not observe a significant correlation between the total tumour volume (not normalized against body weight) or the number of PNF and the age of patients $(\rho=0.22$; $P<$ $0.24 ; \rho=0.11 ; P<0.58)$. By contrast, a correlation between the total tumour volume and the number of tumours was observed $(\rho=0.87 ; P<0.001)$.

\section{Discussion}

The chromosome 9p21.3 region harbours a cluster of important growth regulatory genes (CDKN2A/ARF and $C D K N 2 B)$ that are deleted or transcriptionally silenced in a wide range of tumours such as plexiform neurofibromas (PNF) [12,22]. The proteins encoded by the $C D K N 2 A / C D K N 2 B$ genes act as inhibitors of the CDK4/ 6 cyclin-dependent kinases, thereby regulating the growth suppressive activity of the RB family of proteins. By contrast, the ARF protein binds to and inhibits the oncoprotein MDM2 which activates p53 [11]. The expression of $C D K N 2 A, \mathrm{ARF}$ and $C D K N 2 B$ is very low in both young and non-neoplastic cells but increases during cell aging and oncogene-induced hyperproliferation, suggesting that the coordinated expression of these genes is a means to regulate senescence and prevent oncogene-driven hyperproliferation [11]. The polycomb repressive complexes PRC1 and PRC2 have been shown to initiate and maintain the silenced state of the CDKN2A/ARF, CDKN2B gene cluster [23,24]. PRC1 and $\mathrm{PRC} 2$ are recruited to these loci by the $3.8-\mathrm{kb}$ noncoding RNA ANRIL in order to regulate their expression $[8,10,25,26]$.

In a family-based association study, Pasmant et al. [7] investigated a total of five tag SNPs located at 9p21.3 in 1105 individuals (740 NF1 patients and 365 unaffected individuals from 306 NF1 families) and observed a significant association between the number of PNF and one of these five SNPs, rs2151280. This SNP, located within intron 3 of the ANRIL gene, was found to be associated with the number of PNF under a dominant model, with preferential transmission of the derived T-allele to those NF1 patients possessing a higher number of PNF. By contrast, the number of dermal neurofibromas (DNF) was not found to be associated with rs2151280. Importantly, the T-allele of rs 2151280 is associated with a reduced ANRIL expression level suggesting either a functional role for SNP rs2151280 or that this SNP is in linkage disequilibrium with an additional as yet unknown functional variant which influences ANRIL expression [7]. Taken together, these findings suggested that modulation of ANRIL expression mediates PNF susceptibility in patients with NF1. It is unclear how many patients with NF1 microdeletions were included in the study of Pasmant et al. [7]. However, only 5\% of patients with NF1 exhibit NF1 microdeletions and familial cases are very rare.

In this study, we investigated a putative association between the number or volume of PNF and rs2151280 in 29 patients with non-mosaic NF1 microdeletions. These patients were extremely well characterized by whole-body MRI. We did not observe an association between the T-allele of rs2151280 and either PNF number or PNF volume in these patients, suggesting that this SNP does not exert a strong effect on PNF susceptibility in this group of NF1 microdeletion patients. However, we cannot rule out the possibility of a weak association that might have remained undetected owing to the small number of patients investigated. Under the assumption of an ordered categorical distribution, we estimated that it would have been necessary to analyze approximately 300 NF1 patients to detect a significant association between tumour volume and the T-allele with a power of $80 \%$ using the Mann-Whitney-Wilcoxon test $(\alpha=5 \%)$. This estimation is however based on the observations we made in the 29 patients and implies that the distribution of tumour volumes observed is representative for the whole population of NF1 microdeletion patients. Since NF1 microdeletions are rare (occurring with an estimated prevalence of 1:70,000), the whole-body MRI investigation of 300 patients with NF1 microdeletions is scarcely feasible. As deduced from the data obtained from the analysis of the 29 NF1 microdeletion patients, a strong association between the T-allele of SNP rs2151280 and the PNF load is not obvious.

Patients with NF1 microdeletions have been reported to exhibit a more severe clinical phenotype than patients with intragenic NF1 mutations, as evidenced by an increased risk of MPNSTs, severe learning disability, cognitive impairment, developmental delay and dysmorphic facial features [16,27-30]. However, the number of PNF, as determined by whole-body MRI, was not found to differ significantly between patients with NF1 microdeletions as a group and NF1 patients lacking large NF1 deletions [15]. Nevertheless, differences in PNF development and biology may well exist between both patient groups i.e. those with NF1 microdeletions and those with intragenic NF1 mutations. The most common type of NF1 microdeletion encompasses 1.4-Mb (termed type-1 NF1 deletion) and is associated with the loss of 14 protein- 
coding genes inclusive of the NF1 gene [31-33]. Potentially, the loss of one or several of the genes located within the NF1 microdeletion region in addition to the deletion of the NF1 gene, may influence tumour biology or progression. A good candidate for such a modifier gene influencing tumour development is SUZ12 which is located within the 1.4-Mb NF1 microdeletion region. One allele of SUZ12 is deleted in all patients investigated in our study. The SUZ12 protein is an essential component of the polycomb repressive complex 2 (PRC2) and somatic mutations as well as deletions of SUZ12 have recently been identified in various haematological malignancies indicating an important role for chromatin modifiers (such as the polycomb repressive complexes) in tumorigenesis [34-39]. Remarkably, the polycomb repressive complexes 1 and 2 (PRC1 and PRC2) have also been shown to regulate the expression of the CDKN2A/ARF and CDKN2B genes. ANRIL directly binds to SUZ12, an essential component of PRC2 and is required for SUZ12 occupancy of the $C D K N 2 B$ locus as well as for the epigenetic silencing of $C D K N 2 B$ [8].

The loss of one SUZ12 allele in patients with germline NF1 microdeletions may well influence ANRIL-mediated expression regulation of the $C D K N 2 A / C D K N 2 B$ tumour suppressor genes. Although somatic inactivation of the NF1 wild-type allele is considered to be the PNFinitiating event in NF1 patients with intragenic mutations and patients with NF1 microdeletions [40], both patient groups may differ with regard to tumour progression because of the heterozygous constitutional deletion of SUZ12 present only in patients with NF1 microdeletions. Consistent with this hypothesis, an extremely high total PNF volume $(>3,000 \mathrm{ml})$ was noted significantly more frequently in patients with NF1 microdeletions than in NF1 patients without large deletions [15].

\section{Conclusions}

Our findings in the present study suggest that the putative modulation of ANRIL expression by the T-allele of SNP rs2151280 does not influence PNF susceptibility in patients with NF1 microdeletions. Further studies are however needed in order to investigate possible differences in PNF development or susceptibility in NF1 patients with and without NF1 microdeletions.

\footnotetext{
Abbreviations

ANRIL: Antisense non-coding RNA in the INK4 locus; CDK4/6: Cyclindependent kinases 4 and 6; CD̄KN2A: Cyclin-dēpendent kinase inhibitor 2A; DNF: Dermal neurofibroma; MDM2: Mouse double minute 2 homologue; MPNST: Malignant peripheral nerve sheath tumour; NF1: Neurofibromatosis type-1; PNF: Plexiform neurofibroma; SUZ12: Suppressor of zeste homolog 12; ARF: Alternate open reading frame.
}

\section{Competing interests}

The authors declare that they have no competing interests.

\section{Authors' contributions}

TM carried out the molecular studies and drafted the manuscript. LK, VFM and RN performed the clinical investigations of the patients. JH performed the statistical analysis. HKS and DNC participated in the study design and wrote the manuscript. All authors read and approved the final manuscript.

\section{Acknowledgement}

We are most grateful to our patients and their relatives for contributing samples for this study. This work was funded by the Deutsche Krebshilfe, grant 106982 (VFM and HKS), grant 109713 (RN and VFM), and the Deutsche Forschungsgemeinschaft (DFG), grants KE724/10-1 and KE724/9-1.

\section{Author details}

${ }^{1}$ Institute of Human Genetics, University of Ulm, Albert-Einstein-Allee 11, Ulm, Germany. ${ }^{2}$ Department of Maxillofacial Surgery, University Medical Center Hamburg Eppendorf, Hamburg, Germany. ${ }^{3}$ Department of Neurology, University Hospital Hamburg Eppendorf, Hamburg, Germany. ${ }^{4}$ Institute of Medical Genetics, School of Medicine, Cardiff University, Cardiff, UK.

Received: 24 May 2012 Accepted: 22 October 2012

Published: 26 October 2012

\section{References}

1. Messiaen L, Wimmer K: NF1 Mutational Spectrum. In Neurofibromatoses volume 16. Edited by Kaufmann D. Karger: Monogr Hum Genet; 2008:63-77.

2. Kluwe L, Siebert R, Gesk S, Friedrich RE, Tinschert S, Kehrer-Sawatzki H, Mautner VF: Screening 500 unselected neurofibromatosis 1 patients for deletions of the NF1 gene. Hum Mutat 2004, 23:111-116.

3. Le LQ, Liu C, Shipman T, Chen Z, Suter U, Parada LF: Susceptible stages in Schwann cells for NF1-associated plexiform neurofibroma development. Cancer Res 2011, 71:4686-4695.

4. Evans DG, O'Hara C, Wilding A, Ingham SL, Howard E, Dawson J, Moran A, Scott-Kitching V, Holt F, Huson SM: Mortality in neurofibromatosis 1: In North West England: An assessment of actuarial survival in a region of the UK since 1989. Eur J Hum Genet 2011, 19:1187-1191.

5. Easton DF, Ponder MA, Huson SM, Ponder BA: An analysis of variation in expression of neurofibromatosis (NF) type 1 (NF1): evidence for modifying genes. Am J Hum Genet 1993, 53:305-313.

6. Sabbagh A, Pasmant E, Laurendeau I, Parfait B, Barbarot S, Guillot B, Combemale P, Ferkal S, Vidaud M, Aubourg P, Vidaud D, Wolkenstein P, members of the NF France Network, Adamski H, Baumann-Morel C, BastujiGarin S, Bellanne C, Bieth E, Bousquet P, Brandt C, Balguerie X, Boudali L, Berbis $P$, Castelnau P, Chaix Y, Chevrant-Breton J, Collet E, Cuny JF, Chastagner $P$, Chandeclerc ML, Cheuret $E$, et al: Unravelling the genetic basis of variable clinical expression in neurofibromatosis 1 . Hum Mol Genet 2009, 18:2768-2778.

7. Pasmant E, Sabbagh A, Masliah-Planchon J, Ortonne N, Laurendeau I, Melin L, Ferkal S, Hernandez L, Leroy K, Valeyrie-Allanore L, Parfait B, Vidaud D, Bièche I, Lantieri L, Wolkenstein P, Vidaud M, NF France Network, Adamski H, Baumann-Morel C, Bastuji-Garin S, Bellanne C, Bieth E, Bousquet P, Brandt C, Balguerie X, Boudali L, Berbis P, Castelnau P, Chaix Y, Chevrant-Breton J, Collet $E$, et al: Role of noncoding RNA ANRIL in genesis of plexiform neurofibromas in neurofibromatosis type 1. J Natl Cancer Inst 2011, 103:1713-1722.

8. Kotake Y, Nakagawa T, Kitagawa K, Suzuki S, Liu N, Kitagawa M, Xiong Y: Long non-coding RNA ANRIL is required for the PRC2 recruitment to and silencing of p15(INK4B) tumor suppressor gene. Oncogene 2011, 30:1956-1962.

9. Visel A, Zhu Y, May D, Afzal V, Gong E, Attanasio C, Blow MJ, Cohen JC, Rubin EM, Pennacchio LA: Targeted deletion of the 9p21 non-coding coronary artery disease risk interval in mice. Nature 2010, 464:409-412.

10. Yap KL, Li S, Muñoz-Cabello AM, Raguz S, Zeng L, Mujtaba S, Gil J, Walsh MJ, Zhou MM: Molecular interplay of the non-coding RNA ANRIL and methylated histone $\mathrm{H} 3$ lysine 27 by polycomb CBX7 in transcriptional silencing of INK4a. Mol Cell 2010, 38:662-674.

11. Gil J, Peters G: Regulation of the INK4b-ARF-INK4a tumour suppressor locus: all for one or one for all. Nat Rev Mol Cell Biol 2006, 7:667-677.

12. Beert E, Brems H, Daniëls B, De Wever I, Van Calenbergh F, Schoenaers J, Debiec-Rychter M, Gevaert O, De Raedt T, Van Den Bruel A, de Ravel T, Cichowski K, Kluwe L, Mautner V, Sciot R, Legius E: Atypical neurofibromas 
in neurofibromatosis type 1 are premalignant tumors. Genes Chrom Cancer 2011, 50:1021-1032.

13. Perrone F, Tabano S, Colombo F, Dagrada G, Birindelli S, Gronchi A, Colecchia M, Pierotti MA, Pilotti S: p15INK4b, p14ARF, and p16INK4a inactivation in sporadic and neurofibromatosis type 1-related malignant peripheral nerve sheath tumors. Clin Cancer Res 2003, 9:4132-4138.

14. Nguyen R, Kluwe L, Fuensterer C, Kentsch M, Friedrich RE, Mautner VF: Plexiform neurofibromas in children with neurofibromatosis type 1: frequency and associated clinical deficits. J Pediatr 2011, 159:652-655.

15. Kluwe L, Nguyen R, Vogt J, Bengesser K, Mussotter T, Friedrich RE, Jett K, Kehrer-Sawatzki H, Mautner VF: Internal tumor burden in neurofibromatosis type I patients with large NF1 deletions. Genes Chrom Cancer 2012, 51:447-451

16. Mautner VF, Kluwe L, Friedrich RE, Roehl AC, Bammert S, Högel J, Spöri H, Cooper DN, Kehrer-Sawatzki H: Clinical characterization of 29 neurofibromatosis type- 1 patients with molecularly ascertained $1.4 \mathrm{Mb}$ type-1 NF1 deletions. J Med Genet 2010, 47:623-630.

17. Kehrer-Sawatzki H, Kluwe L, Sandig C, Kohn M, Wimmer K, Krammer U, Peyrl A, Jenne DE, Hansmann I, Mautner VF: High frequency of mosaicism among patients with neurofibromatosis type 1 (NF1) with microdeletions caused by somatic recombination of the JJAZ1 gene. Am J Hum Genet 2004, 75:410-423.

18. Kehrer-Sawatzki H, Schmid E, Fünsterer C, Kluwe L, Mautner VF: Absence of cutaneous neurofibromas in an NF1 patient with an atypical deletion partially overlapping the common $1.4 \mathrm{Mb}$ microdeleted region. Am J Med Genet 2008, 146A:691-699.

19. Kehrer-Sawatzki H, Kluwe L, Fünsterer C, Mautner VF: Extensively high load of internal tumors determined by whole body MRI scanning in a patient with neurofibromatosis type 1 and a non-LCR-mediated 2-Mb deletion in 17q11.2. Hum Genet 2005, 116:466-475.

20. Steinmann K, Kluwe L, Cooper DN, Brems H, De Raedt T, Legius E, Mautner $V F$, Kehrer-Sawatzki $\mathrm{H}$ : Copy number variations in the NF1 gene region are infrequent and do not predispose to recurrent type-1 deletions. Eur $J$ Hum Genet 2008, 16:572-580

21. Roehl AC, Vogt J, Mussotter T, Zickler AN, Spöti H, Högel J, Chuzhanova NA, Wimmer K, Kluwe L, Mautner VF, Cooper DN, Kehrer-Sawatzki H: Intrachromosomal mitotic nonallelic homologous recombination is the major molecular mechanism underlying type-2 NF1 deletions. Hum Mutat 2010, 31:1163-1173.

22. Kim WY, Sharpless NE: The regulation of INK4/ARF in cancer and aging. Cell 2006, 127:265-275.

23. Maertens GN, El Messaoudi-Aubert S, Racek T, Stock JK, Nicholls J, Rodriguez-Niedenführ M, Gil J, Peters G: Several distinct polycomb complexes regulate and co-localize on the INK4a tumor suppressor locus. PLoS One 2009, 4:e6380.

24. Popov N, Gil J: Epigenetic regulation of the INK4b-ARF-INK4a locus: in sickness and in health. Epigenetics 2010, 5:685-690.

25. Yu W, Gius D, Onyango P, Muldoon-Jacobs K, Karp J, Feinberg AP, Cui H: Epigenetic silencing of tumour suppressor gene $\mathrm{p} 15$ by its antisense RNA. Nature 2008, 451:202-206

26. Aguilo F, Zhou MM, Walsh MJ: Long noncoding RNA, polycomb, and the ghosts haunting INK4b-ARF-INK4a expression. Cancer Res 2011, 71:5365-5369.

27. De Raedt T, Brems H, Wolkenstein P, Vidaud D, Pilotti S, Perrone F, Mautner $\checkmark$, Frahm S, Sciot R, Legius E: Elevated risk for MPNST in NF1 microdeletion patients. Am J Hum Genet 2003, 72:1288-1292.

28. Descheemaeker MJ, Roelandts K, De Raedt T, Brems H, Fryns JP, Legius E: Intelligence in individuals with a neurofibromatosis type 1 microdeletion. Am J Med Genet A 2004, 131:325-326.

29. Mensink KA, Ketterling RP, Flynn HC, Knudson RA, Lindor NM, Heese BA, Spinner RJ, Babovic-Vuksanovic D: Connective tissue dysplasia in five new patients with NF1 microdeletions: Further expansion of phenotype and review of the literature. J Med Genet 2006, 43:e8.

30. Pasmant E, Sabbagh A, Spurlock G, Laurendeau I, Grillo E, Hamel MJ, Martin L, Barbarot S, Leheup B, Rodriguez D, Lacombe D, Dollfus H, Pasquier L, Isidor B, Ferkal S, Soulier J, Sanson M, Dieux-Coeslier A, Bièche I, Parfait B, Vidaud $M$, Wolkenstein $P$, Upadhyaya $M$, Vidaud $D$, members of the NF France Network: NF1 microdeletions in neurofibromatosis type 1: from genotype to phenotype. Hum Mutat 2010, 31:1506-1518.
31. Dorschner MO, Sybert VP, Weaver M, Pletcher BA, Stephens K: NF1 microdeletion breakpoints are clustered at flanking repetitive sequences. Hum Mol Genet 2000, 9:35-46.

32. López-Correa C, Dorschner M, Brems H, Lázaro C, Clementi M, Upadhyaya M, Dooijes D, Moog U, Kehrer-Sawatzki H, Rutkowski JL, Fryns JP, Marynen P, Stephens K, Legius E: Recombination hotspot in NF1 microdeletion patients. Hum Mol Genet 2001, 10:1387-1392.

33. Jenne DE, Tinschert $S$, Reimann $H$, Lasinger $W$, Thiel G, Hameister $H$, KehrerSawatzki H: Molecular characterization and gene content of breakpoint boundaries in patients with neurofibromatosis type 1 with $17 q 11.2$ microdeletions. Am J Hum Genet 2001, 69:516-527.

34. Beekman R, Valkhof MG, Sanders MA, van Strien PM, Haanstra JR, Broeders L, Geertsma-Kleinekoort WM, Veerman AJ, Valk PJ, Verhaak RG, Löwenberg B, Touw IP: Sequential gain of mutations in severe congenital neutropenia progressing to acute myeloid leukemia. Blood, . in press.

35. Brecqueville M, Rey J, Bertucci F, Coppin E, Finetti P, Carbuccia N, Cervera N, Gelsi-Boyer V, Arnoulet C, Gisserot O, Verrot D, Slama B, Vey N, Mozziconacci MJ, Birnbaum D, Murati A: Mutation analysis of ASXL1, CBL, DNMT3A, IDH1, IDH2, JAK2, MPL, NF1, SF3B1, SUZ12, and TET2 in myeloproliferative neoplasms. Genes Chrom Cancer, in press.

36. Ntziachristos $P$, Tsirigos A, Van Vlierberghe P, Nedjic J, Trimarchi T, Flaherty MS, Ferres-Marco D, da Ros V, Tang Z, Siegle J, Asp P, Hadler M, Rigo I, De Keersmaecker K, Patel J, Huynh T, Utro F, Poglio S, Samon JB, Paietta E, Racevskis J, Rowe JM, Rabadan R, Levine RL, Brown S, Pflumio F, Dominguez $M$, Ferrando A, Aifantis I: Genetic inactivation of the polycomb repressive complex 2 in T cell acute lymphoblastic leukemia. Nat Med 2012, 18:298-301.

37. Puda A, Milosevic JD, Berg T, Klampfl T, Harutyunyan AS, Gisslinger B, Rumi E, Pietra D, Malcovati L, Elena C, Doubek M, Steurer M, Tosic N, Pavlovic S, Guglielmelli P, Pieri L, Vannucchi AM, Gisslinger $H$, Cazzola M, Kralovics R: Frequent deletions of JARID2 in leukemic transformation of chronic myeloid malignancies. Am J Hematol 2012, 87:245-250.

38. Score J, Hidalgo-Curtis C, Jones AV, Winkelmann N, Skinner A, Ward D, Zoi K, Ernst T, Stegelmann F, Döhner K, Chase A, Cross NC: Inactivation of polycomb repressive complex 2 components in myeloproliferative and myelodysplastic/myeloproliferative neoplasms. Blood 2012, 119:1208-1213.

39. Zhang J, Ding L, Holmfeldt L, Wu G, Heatley SL, Payne-Turner D, Easton J, Chen X, Wang J, Rusch M, Lu C, Chen SC, Wei L, Collins-Underwood JR, Ma J, Roberts KG, Pounds SB, Ulyanov A, Becksfort J, Gupta P, Huether R, Kriwacki RW, Parker M, McGoldrick DJ, Zhao D, Alford D, Espy S, Bobba KC, Song G, Pei D, et al: The genetic basis of early T-cell precursor acute lymphoblastic leukaemia. Nature 2012, 481:157-163.

40. De Raedt T, Maertens O, Chmara M, Brems H, Heyns I, Sciot R, Majounie E, Upadhyaya M, De Schepper S, Speleman F, Messiaen L, Vermeesch JR, Legius E: Somatic loss of wild type NF1 allele in neurofibromas: comparison of NF1 microdeletion and non-microdeletion patients. Genes Chrom Cancer 2006, 45:893-904.

doi:10.1186/1471-2350-13-98

Cite this article as: Mußotter et al:: Non-coding RNA ANRIL and the number of plexiform neurofibromas in patients with NF1 microdeletions. BMC Medical Genetics 2012 13:98.

\section{Submit your next manuscript to BioMed Central and take full advantage of:}

- Convenient online submission

- Thorough peer review

- No space constraints or color figure charges

- Immediate publication on acceptance

- Inclusion in PubMed, CAS, Scopus and Google Scholar

- Research which is freely available for redistribution 